This work was supported in part by U.S. National Institutes of Health grants $M E$ 06-320-03 and $M D$ 00669-05.

Department of Biology,

Western Reserve University, Cleveland, Ohio.

\section{Autogeny and Oviposition in Arctic Mosquitoes}

Two species of mosquito, Aedes (Ochlerotatus) impiger (Walk.) and $A .(O$.$) nigripes (Zett.), occur at Lake Hazen,$ northern Ellesmere Island ${ }^{1}$. This arctic site $\left(71^{\circ} 18^{\prime} \mathrm{W}\right.$., $81^{\circ} 49^{\prime} \mathrm{N}$.), where the Canada Department of Agriculture has conducted entomological studies in 1962 and 1963 , lies within 100 miles of Alert, the most northerly locality at which mosquitoes are known to exist in Canada ${ }^{2}$. Two findings concerning the mosquitoes at Lake Hazen are described here; unless otherwise specified all remarks refer to both aforementioned species.

Numerous temporary and permanent pools provide larval habitats in the area. The most widespread flowering plant is Dryas integrifolia Vahl. (Rosaceae), which adults of both sexes visit frequently to obtain nectar. During tho mosquito flying season (late June-mid-August) about 19 species of bird and 8 species of mammal exist in the area, though at a relatively low density ${ }^{3}$.

At emergence, ovaries of female mosquitoes are in stages I-II of Christophers ${ }^{4}$ and nullipars usually come to bite in stage II, after having mated. Nulliparous and parous females actively seek vertebrate blood and complete ovarian development (that is, reach stage V) about a week after engorgement. However, nullipars can also complete ovarian development, within about the same time, when maintained from emergence with flowers of Dryas integrifolia or with sugar (a 15 per cent solution of sucrose) as their only source of food. Females also oviposited under those conditions, except those A. nigripes maintained on sugar. On such blood-free diets, ovarian development was attended by extensive, stepped degeneration of oocytes, and this so greatly reduced fecundity that sometimes only a single egg attained stage V (Table 1). Females maintained solely on demineralized water survived up to 20 days (cf. up to 37 days on Dryas and sugar) but their ovaries did not develop beyond stage II, and no oocytes degenerated. Evidently access to nectar or sugar is a prerequisite for the procoss leading to degeneration of oocytes and translocation of food reserves in this type of autogenous ovarian devolopment.

In another experiment, females (mixed nullipars and pars) attracted in Nature were allowed to penetrate the skin of the human bait (thus unequivocally manifesting their intention to bite) and then treated in one of two ways : (1) allowed to engorgo ; or (2) removed within $5 \mathrm{sec}$ of having penetrated, presumably before ingestion of blood could have begun. Both groups were then maintained on Dryas and sugar. Ovarian development was then completed in all females $(31 \mathrm{~A}$. impiger and 9 A. nigripes) in group (1), and in $8 / 25$ and $1 / 14$, respectively, in group (2). It therefore appears that in some females (at least) autogeny is facultative. However, until the precise stimulus associated with blood feeding which initiates ovarian development is known, this conclusion must remain provisional.

Autogeny in arctic or subarctic populations of mosquitoes has hitherto been discerned in Aedes (O.) communis (DeGeer) in Canada (although only in populations believed not to tako blood ${ }^{5,6}$, and in $A$. $(O$.$) flavescens (Muller)$ and $A$. (O.) punctor (Kirby) in Sweden? ${ }^{7}$ The present findings establish the existence of autogeny in bloodsucking mosquitoes in arctic North Amorica ; they show that nectar or sugar is required for its manifestation, as in some but not all other autogenous mosquitoss ${ }^{8}$ and that the autogeny is associated with decreased fecundity. They strongly suggest, but do not demonstrate, that autogeny is facultative in individual females. In retrospect, it seems likely that Barlow encountered a similar phenomenon in Aedes (O.) hexodontus Dyar at Churchill, Manitoba, although his use of wild-caught females prevented his reaching certainty on this point.

\begin{tabular}{|c|c|c|}
\hline Treatment & $\begin{array}{c}\text { Aedes } \\
\text { impiger }\end{array}$ & $\begin{array}{c}\text { Aedes } \\
\text { nigripes }\end{array}$ \\
\hline $\begin{array}{l}\text { (A) Emerged in captivity: } \\
\text { Dryas and/or sugar } \\
\text { Dryas and sugar; then blood }\end{array}$ & $\begin{array}{l}1-4(12) * \\
8-23(20)\end{array}$ & $\begin{array}{r}1-16(8) \\
12-41(4)\end{array}$ \\
\hline $\begin{array}{l}\text { (B) Caught biting in Nature: } \\
\text { denied blood; Dryas and sugar } \\
\text { allowed to engorge on blood }\end{array}$ & $\begin{array}{c}2-21(8) \\
12-76(30)\end{array}$ & $\begin{array}{c}7(1) \\
20-47(10)\end{array}$ \\
\hline
\end{tabular}

The pattern of autogeny recognized at Lake Hazen may have special adaptive significance for mosquitoes in the arctic and subarctic, where potential vertebrate hosts fluctuate widely in numbers ${ }^{10}$. It provides for reproductive continuity during years when vertebrates are scarce or absent, and for a proportionate, large increase in years when they aro plentiful. Thus a rich, temporary supply of protein in one year can be used to increase the number of adult females in the next, when, if blood becomes scarce, their greater abundance can to some extent compensate for their reduced fecundity. Accordingly, populations of such mosquitoes probably show numerical fluctuations broadly resembling those of their principal vertebrate hosts; the mosquitoes, however. unlike the vertebrates, will be ensured (by autogeny) against declining beyond $a_{0}$ cortain minimum density.

The second finding to be reported here concerns the oviposition of Aedes nigripes. At Lake Hazen the Sun remains continuously above the horizon (elevation about $\left.6-32^{\circ}\right)^{11}$ throughout the mosquito flying season. Despite this, oviposition is periodic. Females of $A$. nigripes oviposit in clearly visible sites (the characteristics of which will be described elsewhere) frequently rendered conspicuous by the corpses of individuals that die there. Females were often seen ovipositing, but only on surfaces with an aspect currently at right angles (in a horizontal plane) to the rays of the Sun. Laid eggs and dead females in situ were found only in sites directly insolated between 0600 and $2100 \mathrm{~h}$ suntime (solar noon being $1200 \mathrm{~h}$ ); and the overwhelming majority of eggs and females were at sites directly insolated between 1100 and $1300 \mathrm{~h}$. It may be concluded that oviposition is virtually restricted to the period $0600-2100 \mathrm{~h}$ and that it achieves its greatest rate near solar noon. The environmental cues which maintain such periodicity merit study. If, as seems probable, the temperature of the site plays a critical part, the duration of daily oviposition may be expected to decrease as the Sun's maximum daily elevation becomes progressively less during July and August. A consequence of this periodicity is that oviposition sites have a southern to south-westerly aspect and thus are usually among the first parts of the pond margin to become free of snow in June when the overwintered eggs hatch.

\section{PhiltP S. CoRbFT}

Entomology Research Institute,

Canada Department of Agriculture, Ottawa, Ontario.

${ }^{1}$ Oliver, D. R., Arctic, 16, 175 (1963).

2 Bruggemann, P. F., Proc. Tenth Intern. Congr. Ent., Montreal, 1, 695 (1958).

a Savile, D. B. O, and Oliver, D. R., Canad. Field-Nat., 78, 1 (1964).

Christophers, S. R., Paludism, 2, 73 (1911).

s Hocking, B., Nature, 169, 1101 (1952).

- Beckel, W. E., Mosquito News, 14, 124 (1954).

7 Ardö, P., Opusc. Ent., Lund., 23, 171 (1958).

3 Clements, A. N., The Physiology of Mosquitoes (Pergamon Press, London, 1963).

${ }^{8}$ Barlow, C. A., Canad. J. Zool., 33, 420 (1955).

${ }^{10}$ Fiton, C., Voles, Mice and Lemmings (Clarendon Press, Oxford, 1942).

${ }^{11}$ The American Ephemeris and Nautical Almanac (U.S. Naval Observatory washington) 